\title{
Prime ministerial autonomy and intra-executive conflict under semi-presidentialism
}

\author{
Huang-Ting Yan (1) \\ Department of Government, University of Essex, Wivenhoe Park, Colchester CO4 3SQ, UK \\ E-mail: politicshtyan@gmail.com
}

(Received 18 October 2020; revised 27 January 2021; accepted 29 January 2021; first published online 09 March 2021)

\begin{abstract}
This article answers why intra-executive conflict varies across semi-presidential democracies. The literature verifies that intra-executive competition tends to be higher when the president holds less power to dismiss the cabinet, coexists with a minority government, or the president's party is not represented in the cabinet. This paper, therefore, integrates these factors to construct an index of prime ministerial autonomy, proposing that its relationship with the probability of intra-executive conflict is represented by an inverted $\mathrm{U}$-shaped curve. That is, when the prime minister is subordinated to an elected president, or conversely, enjoys greater room to manoeuvre in the executive affairs of the government, the likelihood of conflict is low. In contrast, significant confrontation emerges when the president claims constitutional legitimacy to rein in the cabinet, and controls the executive to a certain degree. This study verifies hypotheses using data on seventeen semi-presidential democracies in Europe between 1990 and 2015.
\end{abstract}

Keywords: intra-executive conflict; power; president; prime minister; semi-presidentialism

\section{Introduction}

Semi-presidentialism is a system of government where a popularly elected president exists alongside a prime minister (PM) and cabinet who are collectively responsible to the legislature (Elgie, 1999). The coexistence of popularly elected presidents and PMs often leads to a gridlock situation under which both actors are not willing to compromise or cooperate. This is because competing legitimacies built into such systems cause the dual executives to claim that they are truly representative of the citizens through direct presidential election or parliamentary support, respectively, and thus lay the grounds for potential conflict between the president and the PM. However, semi-presidential democracies exhibit considerable variation in the chances of intra-executive conflict. Intra-executive coexistence has proven to be peaceful in Ireland compared to most regimes in the post-communist region (Elgie, 2017). A substantial variation in the patterns of intra-executive relationships among semi-presidential regimes has persisted over the first (Protsyk, 2005a; Protsyk, 2006) and second post-communist decades (Sedelius and Ekman, 2010; Sedelius and Mashtaler, 2013). This variation begs the question: under what circumstances do dual executives opt for open confrontation?

There is a substantial body of literature devoted to examining the phenomenon of intraexecutive conflict in semi-presidential regimes by comparing constitutional heterogeneity and political circumstances of semi-presidential systems (Protsyk, 2005a; Protsyk, 2006; Sedelius and Mashtaler, 2013; Elgie, 2017). Several points merit further discussion. First, the literature identifies a too broad (Elgie, 2017) or too narrow (Protsyk, 2005a; Protsyk, 2006; Sedelius and Mashtaler, 2013) scope of constitutional presidential power as a critical source of variation in the political 
control of semi-presidential cabinets. Second, few studies have identified the specific conditions under which cohabitation has an impact on intra-executive conflict (Protsyk, 2005a; Protsyk, 2006; Sedelius and Mashtaler, 2013). ${ }^{1}$ Third, scholars have failed to propose a comparative framework for integrating presidents' motivation and ability to act or to analyse their role in intraexecutive conflict.

This paper proposes that the chances of intra-executive confrontation are shaped by the authority that the constitution grants to the president to pose a threat to the survival of the government and his motivation to exercise that authority. Both factors jointly influence the extent to which the PM determines the executive affairs of the government without presidential intervention. I have, thus, defined and constructed an index of prime ministerial autonomy, proposing that its relationship with the probability of intra-executive conflict is represented by an inverted Ushaped curve. That is, when the PM is subordinated to an elected president, or conversely, enjoys greater room for manoeuvring in the executive affairs of the government, the conflict-likelihood is low. In contrast, significant confrontation emerges when the president claims constitutional legitimacy to rein in the cabinet and controls the executive to a certain degree. This study verifies the hypotheses using data on 187 cabinets in seventeen semi-presidential democracies in Europe between 1990 and 2015.

The work speaks to several central studies in comparative politics. First, this paper argues that the effects of cohabitation on the chances of an intra-executive conflict depend on the president's ability to threaten the government to act on his behalf, thus contributing to existing research on the link between cohabitation and intra-executive conflict (Protsyk, 2005a; Protsyk, 2006; Sedelius and Mashtaler, 2013; Elgie, 2017). Second, this paper adds to the richness of existing scholarship on the relationship between the president's ability to act and his constitutional powers (Protsyk, 2005a; Neto and Strøm, 2006; Protsyk, 2006; Schleiter and Morgan-Jones, 2009b, 2010; Sedelius and Mashtaler, 2013; Elgie, 2017), implying that the PM's willingness to compromise and cooperate increases with presidential influence over cabinet survival. Third, the paper integrates the study of the risk of early government termination across different forms of semi-presidential regimes (Schleiter and Morgan-Jones, 2009a; Sedelius and Ekman, 2010; Kim, 2015; Fernandes and Magalhães, 2016; Yan, 2018), proposing that in addition to cabinet dismissal power, the president can pose a threat to the very survival of the government through the use of assembly dissolution powers or a proposed parliamentary vote of no confidence by his or allied parties. Finally, this study defines and develops an index of prime ministerial autonomy, contributing to a comparative study of measures of cabinet termination power by capturing the multiple steps in the termination processes (Goplerud and Schleiter, 2016).

\section{Prime ministerial autonomy and intra-executive conflict}

Prime ministerial autonomy is defined as the extent to which the PM determines the executive affairs of the government without presidential intervention. There are two parts to this definition. First, the 'prime minister' mentioned here does not refer to the PM itself. This is because cabinet ministers may determine policy outcomes within their respective domains (Laver and Shepsle, 1996) and a largely accommodative agenda is pursued if the government is composed of multiple parties (Warwick, 1999; Martin, 2004; Martin and Vanberg, 2014), thus setting limits on prime ministerial discretion. The first part of the definition, instead, regards the 'prime minister' as one head of the dual executive of a semi-presidential system, that is, a PM heading a cabinet subject to assembly confidence.

Second, semi-presidentialism often generates dual-legitimacy problems, which means that both the president and the PM have competing claims to constitutional legitimacy. A popularly elected

\footnotetext{
${ }^{1}$ The situation in which the president is from one party and the prime minister is from the other one, but where the president's party is absent from government is known as "cohabitation" (Elgie, 2011b).
} 
president derives power from the vote of the people, while a PM leading the government relies on the support of the parliament, which claims to be the citizens' true representative. Protsyk (2005a) explained that popular elections often provide justifications for the president's willingness to rein in the cabinet, intervene in the sphere where the president's formal or informal power is exercised and, thus, control the executive to a certain degree. There are many ways for presidential intervention, such as drawing on assembly dissolution power to threaten the government to act in the president's best interest (Jalali, 2011) or influencing cabinet decisions through invoked public opinion (Neto and Lobo, 2009) combined with their perceived prestige of standing above party politics, especially in a personality-centred political culture (Raunio and Sedelius, 2019). When the chances of presidential intervention in the PM's areas of responsibility are higher, the extent to which the PM determines the executive affairs of the government of his free will is lower. Thus, the second part of the definition, namely, that the PM 'determines the executive affairs of the government without presidential intervention', implies that 'presidential intervention' determines this type of autonomy.

Intra-executive conflict is defined as a political competition between the president and the PM over the control of political resources available to the executive (Protsyk, 2005a; Protsyk, 2006; Sedelius and Ekman, 2010; Sedelius and Mashtaler, 2013). In essence, intra-executive relations are a game where two political actors scramble for a larger share of the pie, especially for that which is not explicitly stipulated by formal procedures on who gets the residual share. As a result, both sides either attempt to change the formal distribution of power or use the existing power to move policy or personnel appointments closer to their ideals (Protsyk, 2005a; Protsyk, 2006), thus grabbing a bigger share of the pie.

If this were the case, it would mean that intra-executive competition is rare when one head of the dual executive determines and regulates government activity with his own free will without the other head's involvement in, for example, economic policy or social affairs. There are two possibilities where one head determines the executive affairs of the government without the other head's intervention in the sphere of his personal policy interest. One possibility is that the PM can exercise nearly full autonomy over policy-making or personnel appointments. In this situation, the president will not exercise any control over the government and the PM acts as the head of government. For instance, in Austria after 1945, Iceland after 1944, and Ireland after 1937, directly elected presidents were introduced in a context where the incumbent was expected to be a figurehead (Elgie, 2011a) and in practice, the presidents were hardly involved in their governments' day-to-day business.

The other possibility is that the president enjoys greater room to manoeuvre in executive affairs and the PM is subordinated to the elected president; in other words, the extent to which the PM can determine the executive affairs of the government is very low. Russia is a case where the president is clearly the dominant figure, and in practice, the presidential features of the Russian semipresidential system appear to have dominated (Baylis, 1996). After 1993, it was the presidency that defined the character of the political system, as Yeltsin used his ascendancy after the dissolution of the parliament to create a constitution that extended his already considerable powers and under which, the PM and his cabinet were completely dependent on the president (White, 1999). For example, Yeltsin could change PMs without providing any explanation, thereby devaluing the post of PM and turning the government into a puppet (Shevtsova and Eckert, 2000).

In contrast, significant tension brews when a president tries to exercise influence over a PM with significant power to advance his or her own agenda. On one hand, the president claims to represent the will of the people and attempts to influence the government's day-to-day business. Romanian President Traian Băsescu proposed a reform of the political system through referendums (Gallagher and Andrievici, 2008: 154); Polish President Lech Kaczyński used his veto power to reject much of the legislation drafted by the government from an attempt to reform inefficient pension systems to a bill restructuring state television (Cienski, 2010). In each instance, the president wanted to make his voice heard in the policy-making process. On the other hand, the 
president is not equipped with sufficient constitutional weapons to subordinate the PM, leaving the PM with some room to manoeuvre. For instance, Romanian PM Călin Popescu-Tăriceanu, through his ruling party, the National Liberal Party, and four allied parties in the parliament, launched an impeachment procedure against Băsescu's unconstitutional conduct (Gherghina and Hein, 2016). Polish PM Donald Tusk, through his ruling party, Civic Platform, prepared a Constitutional Amendment stripping the country's president of his veto power and granting the PM and his cabinet members exclusive power to represent Poland at the EU summit (Polskie Radio, 2010). As a result, both sides intended to be in the driving seat, leading to conflict when the extent to which the PM manages the government's day-to-day business independently falls into the middle range.

In sum, I propose that the relationship between the extent to which the PM determines the executive affairs of the government without presidential intervention and the probability of intra-executive conflict is represented by an inverted U-shaped curve.

\section{Motivation, ability and intra-executive conflict}

This paper has thus far argued that (1) presidential intervention is the determinant of the extent to which the PM determines the government's day-to-day politics, and (2) the relationship between prime ministerial autonomy and intra-executive conflict is represented by an inverted U-shaped curve. This section explores the factors that influence presidential intervention in the executive affairs of the government and its relationship with intra-executive conflict, and proposes that the key factor is the president's motivation and ability.

When the president is not interested in determining and regulating government activity, allowing the PM to manage the government's day-to-day business independently, the level of conflict is low. In contrast, a more active presidential intervention leads both sides to scramble for control over the executive branch of the government.

It seems that the PM engages in open conflict with the president when the head of state intends to impose limits on his decision-making freedom. However, it may not be true if the PM will bear considerable costs after deciding to challenge the president's authority. In other words, the president's ability to turn open confrontation into political suicide for the PM determines whether intra-executive conflict emerges. When the president can ensure the PM's compliance with his decision, intra-executive relations appear less prone to conflict. In contrast, intra-executive relations are marked by rivalry if the president is unable to secure the PM's compliance and cooperation.

Thus, conflict is more likely when the president has sufficient motivation to intervene, but lacks the ability to dominate the PM. This situation is the extent to which the PM independently determines the executive affairs of the government at the mid level. Instead, conflict is rare in semipresidential regimes, where the president has neither the inclination nor the ability to get involved in decision-making processes due to greater prime ministerial autonomy, or where the president dominates the executive leaving the PM with very limited room to manoeuvre. Figure 1 shows the predicted relationship.

\section{Cohabitation, power and intra-executive conflict}

Although this predicted relationship has a theoretical basis, it seems to be empirically implausible for a direct measurement of the president's motivation and ability. This section, thus, proposes that political orientation of the dual executives and the presidential influences over the cabinet's survival jointly determine whether the president intervenes in the executive affairs of the government.

Cohabitation increases the likelihood of intra-executive conflict (Protsyk, 2005a; Protsyk, 2006; Sedelius and Mashtaler, 2013; Elgie, 2017). It is reasonable to expect that the different ideological 

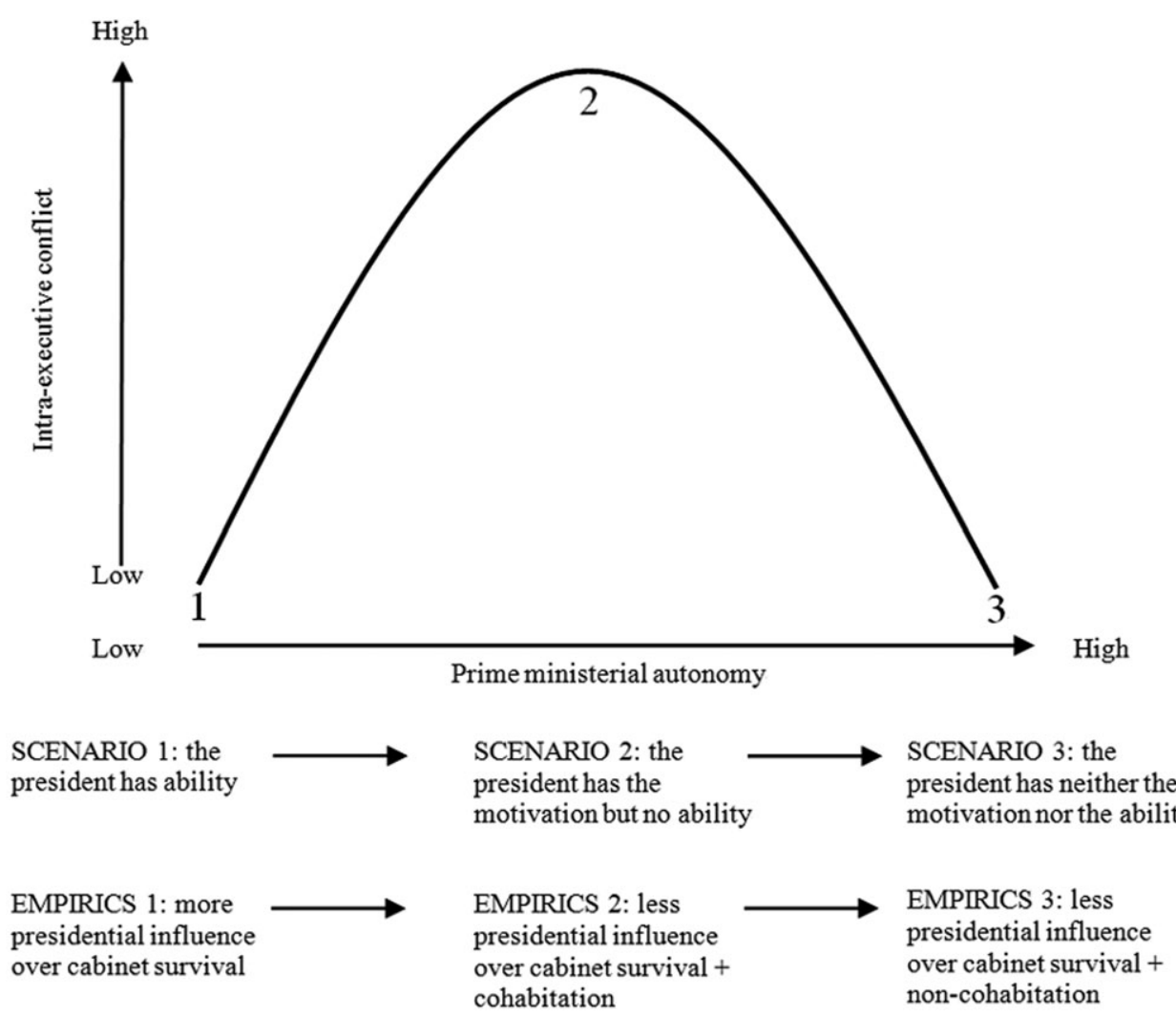

Figure 1. The predicted relation between motivation, ability, prime ministerial autonomy, and intra-executive conflicts and their empirical implications.

Source: the author.

orientations of both executives provide justifications for a presidential intervention because the head of state tries to move policy positions closer to his ideal point and, thus, increases the incentive for intra-executive competition. In other words, a lower consensus between the president and the government coalition creates an incentive for presidents to assert their influence (Tavits, 2008). Existing research points out that during a period of cohabitation, the president is more likely to veto legislation and request a judicial review of bills by the Constitutional Court (Köker, 2017), or get involved in cabinet appointments (Neto and Strøm, 2006), or in other words, presidential activism arises. However, these seminal works cannot explain cases of peaceful intraexecutive relations during the period of cohabitation.

Scholars identify the specific conditions under which cohabitation affects intra-executive conflict (Lazardeux, 2015; Elgie, 2017). Lazardeux's (2015) study of the impact of cohabitation on policy-making in France indicates that electoral incentives determine action on the part of the PM during the cohabitation period. When the PM is optimistic about winning the presidency, he or she will avoid harmful intra-executive conflicts and public criticism by the president, thereby, reducing the number of significant new laws. Conversely, when the PM is less considered a president-in-waiting, the government would be eager to increase the number of enacted significant laws, thus increasing the potential for intra-executive conflict. However, the study was limited by only including three cases of cohabitation. Further, the PM who is unoptimistic about winning the presidency does not necessarily push for significant reforms when the president is equipped with enough constitutional weapons to subordinate the PM. Thus, the president's ability to threaten the government to act on his behalf is the determinant of such a conflict. 
Elgie's (2017) study shows that cohabitation, along with the extent of presidential powers, has a direct impact on the level of intra-executive conflict. That is, intra-executive conflict arises when the president exercises power against a government that cannot support his or her interests under the period of cohabitation. However, the likelihood of confrontations between both executives may not increase with presidential power because the president can, through the use of dismissal powers, pose a direct threat to the government's survival and, thus, increase their willingness to compromise and cooperate. In other words, it seems reasonable to expect conflict to be more frequent when the PM is not afraid of the president's threat and the president has intentions to intervene in the executive affairs of the government. Thus, the president's ability to coerce the government to act on his behalf is crucial, and aggregate measures of presidential powers may not be appropriate.

From a principal-agent perspective, in semi-presidential regimes, voters delegate to two agents, the president and parliament, that acts as the principal of the PM and his cabinet (Schleiter and Morgan-Jones, 2009b). Compared to premier-presidential regimes, president-parliamentary systems provide presidents with cabinet dismissal powers that help to control cabinet survival (Schleiter and Morgan-Jones, 2009a; Sedelius and Ekman, 2010) and prime ministerial turnover (Kim, 2015) and, accordingly, increase prime ministerial incentives not to challenge the presidents' requests, but rather to comply (Protsyk, 2006). Furthermore, the choice of the PM is much closer to the ideal point of presidents with cabinet dismissal power (Protsyk, 2005b). Consequently, intra-executive conflict is rare in president-parliamentary regimes (Protsyk, 2005a; Protsyk, 2006; Sedelius and Mashtaler, 2013).

The author agrees that cabinet dismissal power is an effective weapon to threaten the government, but disagrees that presidential influence on government termination only hinges on such power. In fact, the president, in all probability, secures the PM's compliance through the use of assembly dissolution powers and parliamentary votes of no confidence.

There is a higher possibility that PMs align closely with presidents that have assembly dissolution powers because cabinet survival relies on presidential decisions (Fernandes and Magalhães, 2016). For instance, Portuguese President Jorge Sampaio discouraged PM Durão Barroso from sending troops to Iraq in 2003 by threatening to use his assembly dissolution power, a case of a 'legislative' use of the power of dissolution (Jalali, 2011).

A full understanding of presidential influence on the termination of the government should focus on the other dimension of choice, namely a parliamentary vote of no confidence. First, in all forms of semi-presidentialism, the government must be accountable to the legislature. The government's dependence on parliamentary support means that compulsory resignation happens if the government is deemed by a majority of the members of parliament as no longer fit to govern. Second, although the parliament is granted such power, the president can, through his party or an allied party in the parliament, initiate a motion of no confidence, thus putting the government's survival at risk. For example, Moldovan President Mircea Snegur concluded an alliance with the Popular Front Forces and called on a parliamentary vote of no confidence against PM Andrei Sangheli who attempted to challenge Snegur for the top job (Crowther and Josanu, 2004). Through a proposed motion of no confidence by his allied oligarchy parties in the parliament, Ukrainian President Leonid Kuchma was instrumental in PM Viktor Yushchenko's removal due to his popularity in the opinion polls and his enthusiasm for market reform and pro-Western attitude (Krushelnycky, 2001).

In sum, this paper proposes a direct measurement of the president's motivation as if the dual executives coexist in the period of cohabitation, and the president's ability as presidential influence over cabinet survival through the use of his power to dismiss cabinets, dissolve the parliament, and propose a parliamentary vote of no confidence by his or allied parties. Figure 1 presents the empirical implications. 


\section{An index of prime ministerial autonomy}

This paper has thus far argued in favour of a direct measurement of the president's motivation and ability, which further influences whether the PM can manage the government's day-to-day politics without presidential intervention. This section integrates both factors and develops an index of prime ministerial autonomy.

A PM has greater room to manoeuvre in the executive affairs of government if the PM can prevent the president from exercising his constitutional power to intervene. First, if the chances of the president's willingness to control the executive branch of the government is given as $\mathrm{p}_{\mathrm{m}}$ and that of the president's ability to do it as $\mathrm{p}_{\mathrm{a}}$, the chances of presidential intervention are $\mathrm{p}_{\mathrm{m}}+$ $\mathrm{p}_{\mathrm{a}}-\mathrm{p}_{\mathrm{m}} \times \mathrm{p}_{\mathrm{a}}$. In other words, the probability that one of the two events will occur is the sum of the probability of each event minus the probability of the overlap. The extent to which the $\mathrm{PM}$ determines the executive affairs of the government without presidential intervention, conversely, is $1-\left(p_{m}+p_{a}-p_{m} \times p_{a}\right)$ or $\left(1-p_{m}\right) \times\left(1-p_{a}\right)^{2}$ Second, if the chances that the president, through the use of three types of power, exerts influence over cabinet survival and, accordingly, threatens the government to act on his behalf are depicted as $\mathrm{p}_{1}, \mathrm{p}_{2}, \mathrm{p}_{3}$, based on the same rule, the extent of prime ministerial autonomy is $\left(1-\mathrm{p}_{\mathrm{m}}\right) \times\left(1-\mathrm{p}_{1}\right) \times\left(1-\mathrm{p}_{2}\right) \times\left(1-\mathrm{p}_{3}\right)^{3}$ Thus, this paper used a multiplicative aggregation rule to consider the interplay of constitutional and non-constitutional factors.

The institutional design varies. Some constitutions grant the president a lot of power to dissolve the cabinet. For example, the president can appoint ministers and discharge them (Iceland, Article 15), or dismiss the federal chancellor or the entire federal government (Austria, Article 70), while others do not provide the president with such constitutional weapons, such as Bulgaria, Ireland, and Slovenia. In the 17 semi-presidential democracies analysed in this paper, except Portugal (1982, Article 198-2) and the Ukraine (2004, Article 87), all constitutions either grant or do not grant the president the power to terminate the cabinet. ${ }^{4}$ Thus, I gave a probability of 1 for the president who can direct such powers against the cabinet without any hindrance, and 0 for otherwise. ${ }^{5}$

In conceptualising the assembly dissolution powers, Goplerud and Schleiter (2016) captured five dimensions of variations that jointly define the scope of an actor's (e.g., president) power, including the agenda setting role (initial actors), trigger (final actors), collective decision rule, conditionality, and time barriers, thus developing an index of the president's power to dissolve parliament (0-10). I divided the scores by ten for a scale from 0 to 1 to assess the chances of presidential influence over cabinet survival through the use of such power.

It helps to measure presidential influence over cabinet survival through a proposed motion of no confidence by his party or allied parties in parliament. Yan (2018) investigated party systems to measure how the parliament exercises the power to terminate the cabinet by a vote of no confidence. First, he identified four dimensions of institutional variation in multiple steps to launch a successful vote of no confidence, including the agenda setting role, trigger, collective decision rule,

\footnotetext{
${ }^{2}$ It reflects the probability that the president has neither the inclination nor the ability to get involved in the decisionmaking process.

${ }^{3}$ If two events can occur simultaneously, they are said to be non-mutually exclusive events. In other words, there is a certain probability that the president simultaneously poses a very threat to the survival of government through the use of three types of power.

${ }^{4}$ The presidents in both countries have limited power to dismiss the cabinet. In Portugal, the President of the Republic may dismiss the government only when this becomes necessary to secure the regular functioning of the democratic institution and after the Council of State has been consulted (see Article 198-2). In the Ukraine, the Verkhovna Rada, on the proposal of the President of the Ukraine, may consider the issue of the responsibility of the Cabinet of Ministers and adopt a resolution of no confidence in the Cabinet of Ministers by the majority of the constitutional composition of the Verkhovna Rada (see Article 87).

${ }^{5}$ For the two cases, Portugal (1982) and the Ukraine (2004), a probability of 0 is given because the presidents in both countries do not wield unrestricted power to dismiss the cabinet.
} 
and conditionality, ${ }^{6}$ using a probabilistic logic to measure this type of cabinet termination power. Second, considering real political situations, he assumed that MPs do not act individually but rather support the policies of their party leadership and vote according to the wishes of their party. ${ }^{7}$ Third, he assumed that MPs from parties of coalition cabinets cooperate to vote against motions of no confidence tabled by opposition parties, reflecting that minority governments are more likely to die by the parliament's (or the president's) hand because of their inherent structural and political weakness.

For example, in Bulgaria at least one-fifth of MPs (Article 89, that is, 48 of total 240 MPs, Article 63) can submit an interpellation to measure confidence in the government. The parliament can play both the role of a proposer and a trigger to determine the success or failure of the proposed cabinet termination, and the probability of a given proposal entering into the decision-making procedures is, thus, (1) In order to be passed, the motion requires a majority of more than half of the MPs' votes (Article 89). No conditionality applies in this case. For Borisov's cabinet (2009-2012), where a single ruling party GERB (116 seats) faced five opposition parties, KzB (40 seats), DPS (38 seats), Ataka (21 seats), SK (15 seats), and RZS (10 seats), the probability is as follows:

$$
\begin{gathered}
\text { Initial actor (parliament), } \mathrm{P}\left(\mathrm{I}_{\text {parl }}\right)=\frac{\mathrm{C}_{2}^{5}-\mathrm{C}_{2}^{3}+\mathrm{C}_{3}^{5}-\mathrm{C}_{3}^{3}+\mathrm{C}_{4}^{5}+\mathrm{C}_{5}^{5}}{2^{5}}=0.688 \\
\text { Trigger (parliament), } \mathrm{P}\left(\mathrm{T}_{\text {parl }}\right)=1 \\
\text { Collective action rule (parliament), } \mathrm{P}\left(\mathrm{R}_{\text {parl }}\right)=\frac{\mathrm{C}_{5}^{5}}{2^{5}}=0.031
\end{gathered}
$$

No conditionality

$$
\mathrm{P}\left(\mathrm{I}_{\text {parl }}\right) * \mathrm{P}\left(\mathrm{T}_{\text {parl }}\right) * \mathrm{P}\left(\mathrm{R}_{\text {parl }}\right)=0.688 * 1 * 0.031=0.021
$$

Thus, I recorded the scores $(0-1)$ for each cabinet. ${ }^{8}$

I gave the president who coexisted with the PM of a different ideological orientation a probability of 0.5 , and 0 otherwise. I chose 0.5 instead of 1 to investigate the varying effects of presidential influences over cabinet survival on the extent to which the PM independently manages the government's day-to-day politics during the period of cohabitation. More precisely, if 1 is assigned, the extent of prime ministerial autonomy is 0 , showing the same effect where the president exerts either more or less influence on the length of the government's tenure, thus making it unlikely for the theories to be evaluated empirically.

Based on the operationalisation described above, the extent of prime ministerial autonomy in Borisov's cabinet (2009-2012), as an illustrative example, is reflected in the following coding:

The Bulgarian constitution does not provide the president with the power to dismiss the cabinet: $\mathrm{p}_{1}=0$.

The Bulgarian constitution does not provide the president with the power to dissolve the parliament: $\mathrm{p}_{2}=0$.

\footnotetext{
${ }^{6}$ Agenda-setting roles are played by actors who have the power to propose and place cabinet termination on the political agenda. A trigger is defined as a political actor who can determine the success or failure of the proposed cabinet termination. The probability of making a resolution is conditioned on an initial actor's capacity to set this agenda. If an actor plays the roles of both proposer and trigger, the probability of a given proposal entering the decision-making process is 1 . In the case of a vote of no confidence, the parliament plays both roles. The probability is, thus, 1 . The collective decision rule refers to the rule, including simple majority, absolute majority, and qualified majority, by which triggers achieve internal consensus. Conditionality adds extra constraints on how actors use constitutional power to dismiss the cabinet, that is, an actor takes a decision upon receiving the assent of others. For the case of a vote of no confidence, it indicates if a constructive vote of no confidence is adopted.

${ }^{7}$ Independents were calculated as if they were individual parties with one seat each.

${ }^{8}$ See Appendix A (online) for more examples.
} 
Table 1. Illustrative cases and Expected levels of intra-executive conflicts

\begin{tabular}{|c|c|c|c|c|c|c|}
\hline \multirow[b]{2}{*}{ Case } & \multicolumn{3}{|c|}{ The President's Ability } & \multirow{2}{*}{$\frac{\text { The President's Motivation }}{\text { Cohabitation }\left(\mathrm{p}_{\mathrm{m}}\right)}$} & \multirow{2}{*}{$\begin{array}{l}\text { Prime Ministerial Autonomy } \\
\text { Scores }\left(1-p_{m}\right) \times\left(1-p_{1}\right) \times \\
\left(1-p_{2}\right) \times\left(1-p_{3}\right)\end{array}$} & \multirow[b]{2}{*}{$\begin{array}{l}\text { Expected Levels } \\
\text { of Conflicts }\end{array}$} \\
\hline & $\operatorname{CAP}\left(\mathrm{p}_{1}\right)$ & $\operatorname{ADP}\left(p_{2}\right)$ & $\operatorname{PNC}\left(p_{3}\right)$ & & & \\
\hline Case 1 & 0 & 0 & 0 & 0 & 1 (none) & Low \\
\hline Case 2 & 0 & 0 & 0 & 0.5 & $0.5(\mathrm{M})$ & High \\
\hline Case 3 & 0 & 0.3 & 0 & 0 & 0.7 (none) & Low \\
\hline Case 4 & 0 & 0.3 & 0 & 0.5 & $0.35(\mathrm{M})$ & High \\
\hline Case 5 & 0 & 0.8 & 0 & 0 & $0.2(\mathrm{~A})$ & Low \\
\hline Case 6 & 0 & 0.8 & 0 & 0.5 & 0.1 (A\&M) & Low \\
\hline Case 7 & 1 & 0.4 & 0 & 0 & $0(A)$ & Low \\
\hline Case 8 & 1 & 1 & 0 & 0.5 & $0(A \& M)$ & Low \\
\hline
\end{tabular}

Note: CAP, cabinet dismiss power; ADP, assembly dissolution power; PNC, a parliamentary vote of no-confidence; none in parentheses, the president has neither the ability nor the motivation; $M$, the president has motivation; $A$, the president has ability; $A \& M$, the president has both the ability and the motivation. Case 1: Kostov's cabinet (1997-2001), Bulgaria; Case 2: Videnov's cabinet (1995-1997), Bulgaria; Case 3: Sanader's cabinet (2003-2006; 2006-2008), Croatia; Case 4: Kosor's cabinet (2010-2011), Croatia; Case 5: Guterres's cabinet (1999-2002), Portugal; Case 6: Barroso's cabinet (2002-2004), Portugal; Case 7: Fradkov's cabinet (2004-2007), Russia; Case 8: Oddsson's cabinet (1996-1999), Iceland.

The presidential influence over cabinet survival through a proposed motion of no confidence by his party or allied parties in the parliament: $\mathrm{p}_{3}=0.021$.

Cohabitation applies in this case, so the chances of the president's willingness to control the executive branch of the government: $\mathrm{p}_{\mathrm{m}}=0.5$.

The extent of prime ministerial autonomy is $\left(1-\mathrm{p}_{1}\right) \times\left(1-\mathrm{p}_{2}\right) \times\left(1-\mathrm{p}_{3}\right) \times\left(1-\mathrm{p}_{\mathrm{m}}\right)=$ 0.490 .

Table 1 presents some real cases based on this coding rule. The PM can determine the executive affairs of the government independently when the president has neither the inclination nor the ability (case 1 , score of 1 ) or has a very limited ability to intervene (case 3 , score of 0.7 ). The extent of prime ministerial autonomy, however, falls into the middle range when the president's willingness increases during the period of cohabitation (cases 2 and 4, scores of 0.5 and 0.35). It drops abruptly when the president has greater influence over cabinet survival through the use of considerable power to dissolve the parliament (case 5, score of 0.2 ) or unrestricted power to dismiss the cabinet (case 7, score of 0 ) irrespective of the political orientation of both executives (cases 6 and 8 , scores of 0.1 and 0 ). Thus, the index certainly illustrates the extent to which the PM manages the executive affairs of government without presidential intervention.

This new measure has certain advantages over existing indices of presidential power. Scholars have measured political actors' power to remove the cabinet through dichotomous measures (Siaroff, 2003), the use of a 0 to 4 ordinal scale (Shugart and Carey, 1992; Metcalf, 2000), or different weights under various institutional structures (McGregor, 1994; Hellman, 1996; Frye, 1997), which theoretically fails to capture the complexity of the constitution and ignores multiple paths of cabinet termination, and is empirically not enough to answer questions this article presents. If an ordinal scale were used, there would remain considerable variation in the levels of intra-executive conflict across countries where the president is not granted cabinet dismissal power. Further, these methods fail to provide reasonable justification of weights on presidential power. Finally, existing additive indices measuring presidential power fail to provide a link between the different power dimensions of a president's ability to threaten the government. Instead, the use of a multiplicative aggregation rule reflects a constraint on a president's ability to terminate the cabinet on any one power dimension, thus determining the extent to which the PM determines the executive affairs of the government without presidential intervention. It also checks the recurrence of similar problems on the choice of weights and, thus, is more persuasive. 
In sum, a more nuanced measure enables scholars to compare presidential influences on securing the government's compliance and cooperation.

\section{Research design}

First, terms were defined. The unit of analysis was 'cabinets of semi-presidential democracies'. This paper used the Polity IV Project ${ }^{9}$ to define a 'democracy' as being the presence of institutions and procedures by which executive power is checked and through which citizens can express effective preferences on alternative policies and leaders and, thus, selected countries that maintained a democracy for at least five years between 1990 and 2015. 'Semi-presidentialism' occurs when a constitution provides for a directly elected fixed-term president and a PM and cabinet collectively responsible to the legislature (Elgie, 1999). A new 'cabinet' is installed whenever there is a change in the set of parties holding cabinet memberships, a change in PMs, or a parliamentary election (Müller and Strøm, 2000). Therefore, our data covered 187 cabinets in seventeen semi-presidential democracies.

The dependent variable was the level of intra-executive conflict. Following Sedelius and Mashtaler (2013), a dummy variable coded 1 for 'there had been an observable clash between the president and the PM and/or between the president and cabinet ministers, manifested through obstructive or antagonistic behaviour from either side, directed towards the other' and 0 for no conflict or only episodic or isolated instances of tensions. This paper determined the level using the literature, conventional country reports, newspaper articles, and academic blog articles, including East European Constitutional Review, Freedom House's Nations in Transit, Parliaments and Governments Database, The Political Data Yearbook of the European Journal of Political Research, Elgie's two blogs: The Semi-Presidential One and Presidential Power, DELFI by the Lithuania Tribune, Dziennik Związkowy-Polish Daily News, Independent Balkan News Agency, Nacional.hr-Dnevno online izdanje, Novinite.com-Sofia News Agency, Prague Post Magazine, Radio Free Europe/Radio Liberty, The Daily Slovakia, and The Slovenia Times etc.

Some examples demonstrating how such a coding rule works are as follows. President Zeman criticised PM Sobotka, who sent more troops to Central and Eastern Europe in response to tensions in the Ukraine and the Russian annexation of Crimea. Sobotka took the opposite stance of Zeman, who said that NATO troops would enter the Ukraine if Russia extended its military operations outside Crimea. This presents antagonistic behaviour from both sides and, thus, the conflict level is high. Furthermore, some high-conflict cases show obstructive actions directed towards the other, such as a presidential veto of a measure of the government to repay foreign governments for their bailouts (Iceland, President Grimsson), impeachment attempts against the president (Bulgaria, PM Borissov), refusal to appoint (Romania, President Băsescu) or remove (Portugal, PM Santana Lopez) cabinet ministers, and a call for a parliamentary vote of no confidence against the government (Moldova, President Sengur). Appendix B (online) presents the level of intraexecutive conflict in 187 cabinets, and Appendix C summarises the issues of conflict.

As indicated in Sedelius and Mashtaler's seminal work (2013), this coding rule has not delivered an absolute and exact criterion for when a conflict is to be considered 'durable' enough. For the purpose of reliability, I compared the results of coding of the level with Protsyk (2006), Sedelius and Mashtaler (2013), and Elgie (2017), where the last two conducted an expert survey, finding, except for a very small number of cases, that the results of cases that recorded a value of 0 or 1 were consistent across the four comparative studies.

Next, a list of control variables influencing the levels of intra-executive conflict was added. First, the president's personal background may contribute to intra-executive conflicts (Baylis, 1996). Prior experience as a party leader enables the president to employ party resources to empower factions and to develop political skills to broker compromises with opposition parties, interact

${ }^{9}$ Polity IV project: https://www.systemicpeace.org/polity/polity4.htm. 
well with constituencies, and manage relationships with the press or members of parliament from the same camp, thus making it easier for the president to intervene in executive affairs. Therefore, I introduced a dummy variable coded 1 for president with experience as a party leader. Second, I considered the effect of the presidential term. Intra-executive competition either rises with the newness of their mandates (Elgie, 2017; Köker, 2017) or as presidential elections approach, due to the presidents' attempts to control succession (Protsyk, 2006). This paper, thus, added two dummy variables of which the first term presidency variable was coded 1 for a cabinet that coexisted with the president during the first year of a presidential term, while the late term presidency variable was given a score of 1 following the same coding rule.

Third, a consolidated democracy decreases the probability of conflict (Protsyk, 2006; Elgie, 2017). Thus, I captured this effect by including the natural log of the age of democracy, which is calculated as a period starting from the year in which democratic transitions occurred to each year a new cabinet was formed using Polity IV datasets. Further, the transition variable, a dummy created where $1=$ the first popularly elected president after democratisation and $0=$ otherwise, was included in the analysis. Finally, following Elgie (2017) and studies of presidential activism (Neto and Strøm, 2006; Schleiter and Morgan-Jones, 2009b, 2010; Köker, 2017), I included the effective number of legislative parties and the number of parties in the government from the ParlGov dataset ${ }^{10}$ and expected that as the numbers increased, the intra-executive relations would get more conflict prone. Appendix D presents the descriptive statistics of the variables described above. I tested to see if prime ministerial autonomy was related to intra-executive conflict through an inverted U-shaped curve using logistic regression with a robust standard error cluster for countries.

For robustness, first of all, semi-presidentialism is characterised by not only constitutional heterogeneity but also political circumstances as well. Despite the presidents in Austria and Iceland being granted power to dissolve the parliament and to dismiss the government, they refrained from intervening in day-to-day politics. Thus, these powers have not been used since 1945 (Elgie, 1999). This study, thus, excluded the effects of the pathway through which the president could terminate cabinets on the limits to prime ministerial autonomy in both countries, and changed their index scores.

Second, based on original measurements, when a president poses a very real threat to the survival of governments through, for instance, the use of cabinet dismissal power, the status of cohabitation, or not, cannot add this dimension of variation that defines the index of prime ministerial autonomy jointly with other dimensions. For example, the 1996 Ukrainian constitution provides the president with unrestricted power to dismiss the cabinet $\left(\mathrm{p}_{1}{ }^{\text {original }}=1\right)$, the score of prime ministerial autonomy is $0\left(1-\mathrm{p}_{1}{ }^{\text {original }}\right)$, regardless of the status of cohabitation $\left[\mathrm{p}_{\mathrm{m}}=0.5,\left(1-\mathrm{p}_{1}{ }^{\text {original }}\right) \times\left(1-\mathrm{p}_{\mathrm{m}}\right)=0\right]$ or not $\left[\mathrm{p}_{\mathrm{m}}=0,\left(1-\mathrm{p}_{1}{ }^{\text {original }}\right) \times\left(1-\mathrm{p}_{\mathrm{m}}\right)=0\right]$. This paper, thus, changed the rule using a penalty factor of 0.05 as a slight constitutional constraint on the president's use of such power. The reason for this alternative choice was that it could consider the interplay of constitutional and non-constitutional factors even if the constitution granted the president much power to end cabinets. In the case of Ukraine, if a penalty factor of 0.05 is added as a constitutional constraint on the president's use of power to dismiss the cabinet $\left(\mathrm{p}_{1}{ }^{\text {original }}=1, \mathrm{p}_{1}{ }^{\text {new }}=0.95\right)$, the score of prime ministerial autonomy is $0.05\left(1-\mathrm{p}_{1}{ }^{\text {new }}\right)$, and under the period of cohabitation, it is reduced to $0.025\left[\mathrm{p}_{\mathrm{m}}=0.5,\left(1-\mathrm{p}_{1}{ }^{\text {new }}\right) \times\left(1-\mathrm{p}_{\mathrm{m}}\right)=0.025\right]$, compared to a score of 0.05 if cohabitation were to end $\left[p_{m}=0,\left(1-p_{1}{ }^{\text {new }}\right) \times\left(1-p_{m}\right)=0.05\right]$.

Third, the results of coding in this study and the two comparative studies (Protsyk, 2006; Elgie, 2017) cannot arrive at a consensus on a small number of cases that recorded a value of 0 or 1 in the levels of intra-executive conflict. This paper, thus, changed the values in these cases to arrive at an agreement.

\footnotetext{
${ }^{10}$ ParlGov dataset: http://www.parlgov.org.
} 
Finally, this paper excluded the case Russia with its questionable levels of democracy - in the alternative measure (Geddes et al., 2014; Bjørnskov and Rode, 2020) it was a non-democracy. This is because a dictator serving as a president rewards loyalty by recruitment to the cabinet, which can be reshuffled with ease, thus raising the head of government's willingness to comply with the president's action.

\section{Results}

Figure 2 presents the relationship between prime ministerial autonomy and intra-executive conflict as an inverted U-shaped curve. Based on the results of the univariate regression analyses, while the probability of confrontations between the dual executives is approximately 0.15 with scores of prime ministerial autonomy at 0 , it becomes 0.36 with a score of 0.5 . Further, when the scores of prime ministerial autonomy reach 0.8 and 1 , the predicted probability of conflict drops to 0.24 and 0.11 , respectively. Similarly, Figure 2 verifies the inverted U-shaped relationship through the addition of controls and a test of robustness.

\section{Test of causal mechanism: quantitative analysis}

If my theoretical argument is true, we can expect that a president's willingness to control the executive branch during a period of cohabitation will increase intra-executive competition only in semi-presidential democracies where the president cannot pose a threat to cabinet survival. To test this, the interaction term was computed as: 'cohabitation $\times$ presidential influences over cabinet survival', where cohabitation is a dummy variable, $1=$ cohabitation and $0=$ otherwise, and presidential influences over cabinet survival is a continuous one (0-1), identifying a multi-pathway cabinet termination and measuring the chances of a president's use of power to dissolve the government. The study used a multiplicative aggregation rule to link the three paths that a president could initiate to end the cabinet, that is, the use of cabinet dismissal power, assembly dissolution power, or through his party or allied parties in the parliament, the use of a motion of no confidence. Similarly, I also controlled for the seven variables mentioned previously.

Figure 3 provides strong support for the causal mechanism. In semi-presidential democracies where the president cannot pose a threat to cabinet survival, when compared to their counterparts where the president has the final say on the government's survival, cohabitation increases the chances of confrontation between both political actors. Further, in contrast with the period of cohabitation, this effect is not identified in situations in which the president and the PM of the same political orientation coexist, confirming my theoretical expectations that no matter how much influence the president has on early government termination, conflict is not frequent when both actors share the same ideological orientation.

Figure 4 shows the conditional effects of cohabitation on the predicted probability of intraexecutive conflict. The difference in the effects between the cohabitation and non-cohabitation groups decreases with the values of presidential influence over cabinet survival. Therefore, it lines up with the argument that the greater a president's influence on cabinet termination, the lower the level of intra-executive conflicts, irrespective of the political orientation of both executives.

\section{Test of causal mechanism: csQCA}

The second method used in this study was qualitative comparative analysis (QCA). Developed by Charles Ragin (2008), QCA is a configurational method that seeks to explore the relationship between the combination of 'conditions' and 'outcomes'. QCA is also a technique designed for small$\mathrm{N}$ or intermediate- $\mathrm{N}$ research, a synthesis of in-depth insight across cases and the generalisation of multiple causal paths, and combines the best features of the case-oriented approach with those of the variable-oriented approach (Ragin, 2008). Three types of QCA are widely applied, and this 

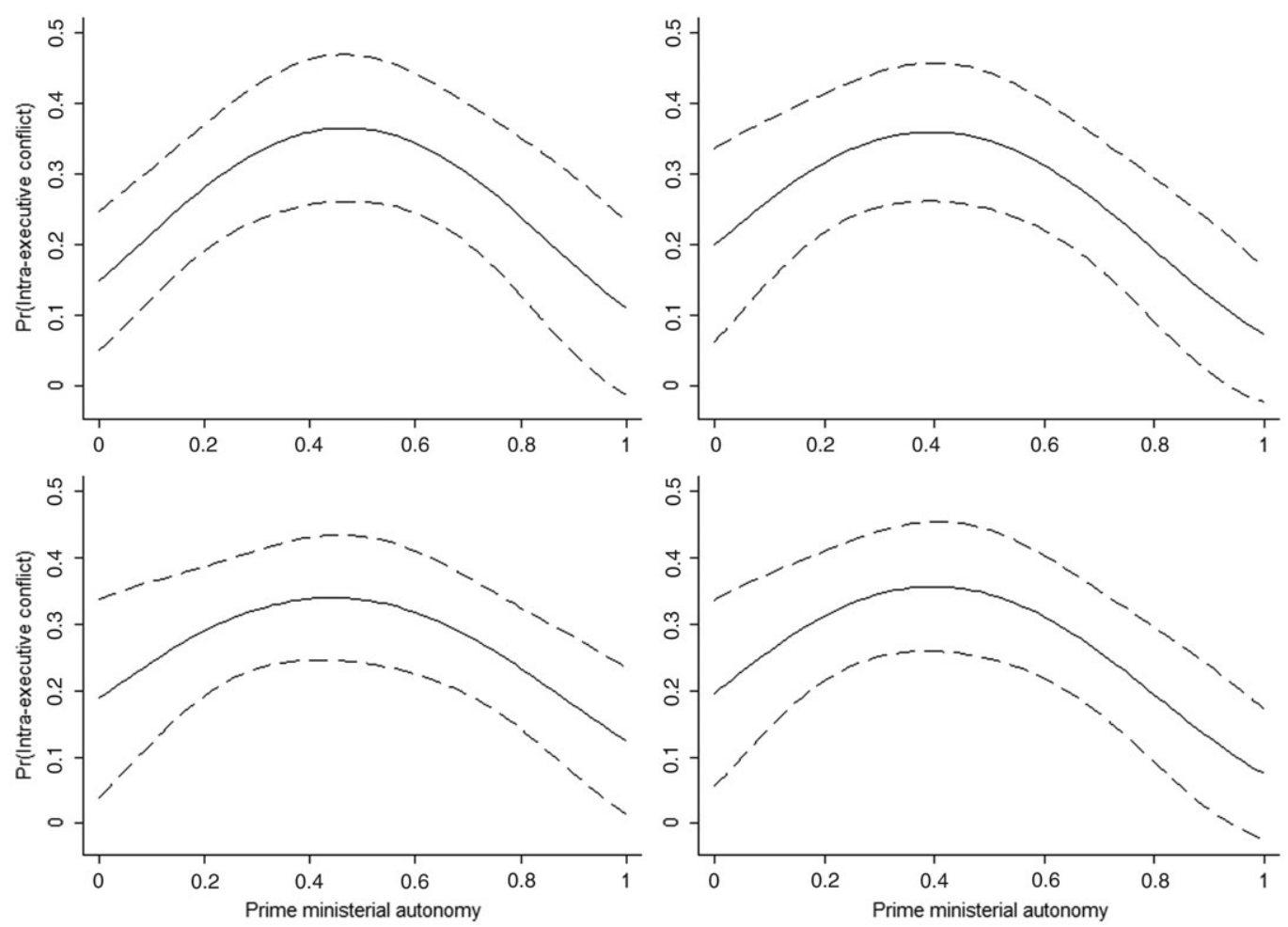

Figure 2. Prime ministerial autonomy and intra-executive conflicts.

Note: Based on the models reported in Columns 1 and 4 of supplementary Table 1, Appendix E. Upper-left panel: model 1, upper-right panel: model 2, lower-left panel: model 3, lower-right panel: model 4.

study chooses crisp-sets QCA (dichotomous variable, csQCA) because all the conditions and outcome factors are bivalent (Thiem, 2014).

The csQCA method hinges on the logic of Boolean algebra. By Rihoux and De Meur's (2009) standard operating procedure, first, the researcher must construct a dichotomous data table, consisting of 0 or 1 attributed to conditions and outcomes. Based on that, a truth table or the table of configurations - a given outcome corresponding to the combination of conditions - is produced. After addressing the possible contradictory configurations, the key step, Boolean minimisation, is run to find the complex, intermediate-to-parsimonious formula that will be interpreted by the researcher afterwards.

In this study, there were 187 cases. The outcome variable, CONFLICT, is already of a dichotomous nature, where $1=$ higher levels of intra-executive conflict and $0=$ otherwise. We have four bivalent conditions, of which COHABIT captures whether the president represents a different party to the PM, and whether the president's party is absent from government. The other three reflect the degree to which the PM controls executive power. That is, DISPARL delineates the president's power of initiating the dissolution process by simply and directly placing such a motion on the political agenda, and thus, dissolving the parliament at his own will; DISCAB records whether the president can dismiss ministers without the consent of the assembly. NOCONF is coded 1 when the government formed by a party or coalition of parties, does not have a majority of overall seats in the parliament, and the MPs use the simple majority rule to determine that the government is no longer deemed fit to hold that position.

The truth table shows that some configurations are associated with a negative outcome $(0)$, while others are associated with a contradictory outcome in which cases are coded 1 on the 

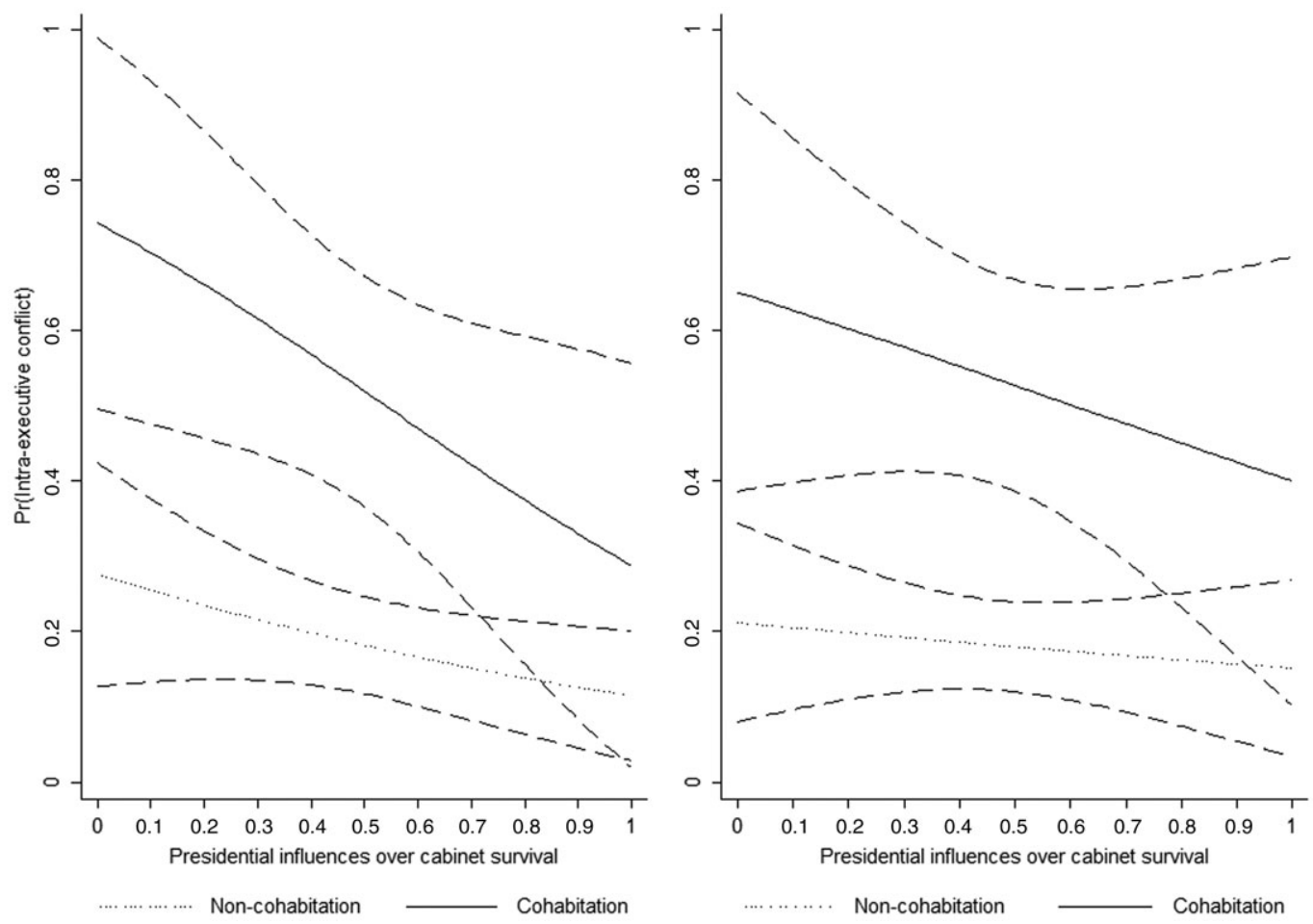

Figure 3. Presidential influences over cabinet survival, cohabitation and intra-executive conflicts.

Note: Left panel: no control model (the slope for cohabitation group: $-0.448^{\star \star}$, for non-cohabitation group: -0.159 ), right panel: control model (the slope for cohabitation group: $-0.238^{\star}$, for non-cohabitation group: -0.061 ). ${ }^{\star} \mathrm{P}<0.1,{ }^{\star \star} \mathrm{P}<0.05,{ }^{\star \star \star} \mathrm{P}<0.01$.

outcome of interest and others are 0 (Appendix F-1). Resolving contradictory configurations is a vital issue that can be achieved using statistical methods that compare the distribution of outcomes between specific configurations and others (Roscigno and Hodson, 2004), or quasisufficiency, which assigns the outcome to the contradictory configurations in which the majority of cases appear (Skaaning, 2011).

Further, in the truth table, there are some logically possible configurations in which nonobservable cases fit, which are defined as logical remainders. Conventionally, there are three strategies to tackle this problem. A conservative approach is to treat all logical remainders as false, while the other strategy treats them as don't care to generate the most parsimonious formula. However, the first approach leads to formulae that are too complex for a theoretically meaningful interpretation, but the second one includes some logical remainders without theoretical or empirical support. A third approach, based on so-called easy counterfactuals, is in line with the existing knowledge that the presence (or absence) of conditions is linked to outcome 0 or 1 , and finds a solution term of intermediate complexity (Ragin and Sonnett, 2004). Standards of good practice in QCA produce and report three formulae: complex, intermediate, and the most parsimonious (Schneider and Wagemann, 2010).

As for the robustness check, one way to test if similar results emerge is through a reduction, addition, or replacement of explanatory factors (Skaaning, 2011). Supplementary Table 1 shows that intra-executive conflict in democracies decreases over time after the transition to democracy. This leads to an expectation that this type of conflict will increase in post-communist countries where their political systems are more unstable when compared to the six consolidated democracies of Austria, Finland, France, Iceland, Ireland, and Portugal. This paper, therefore, added the 

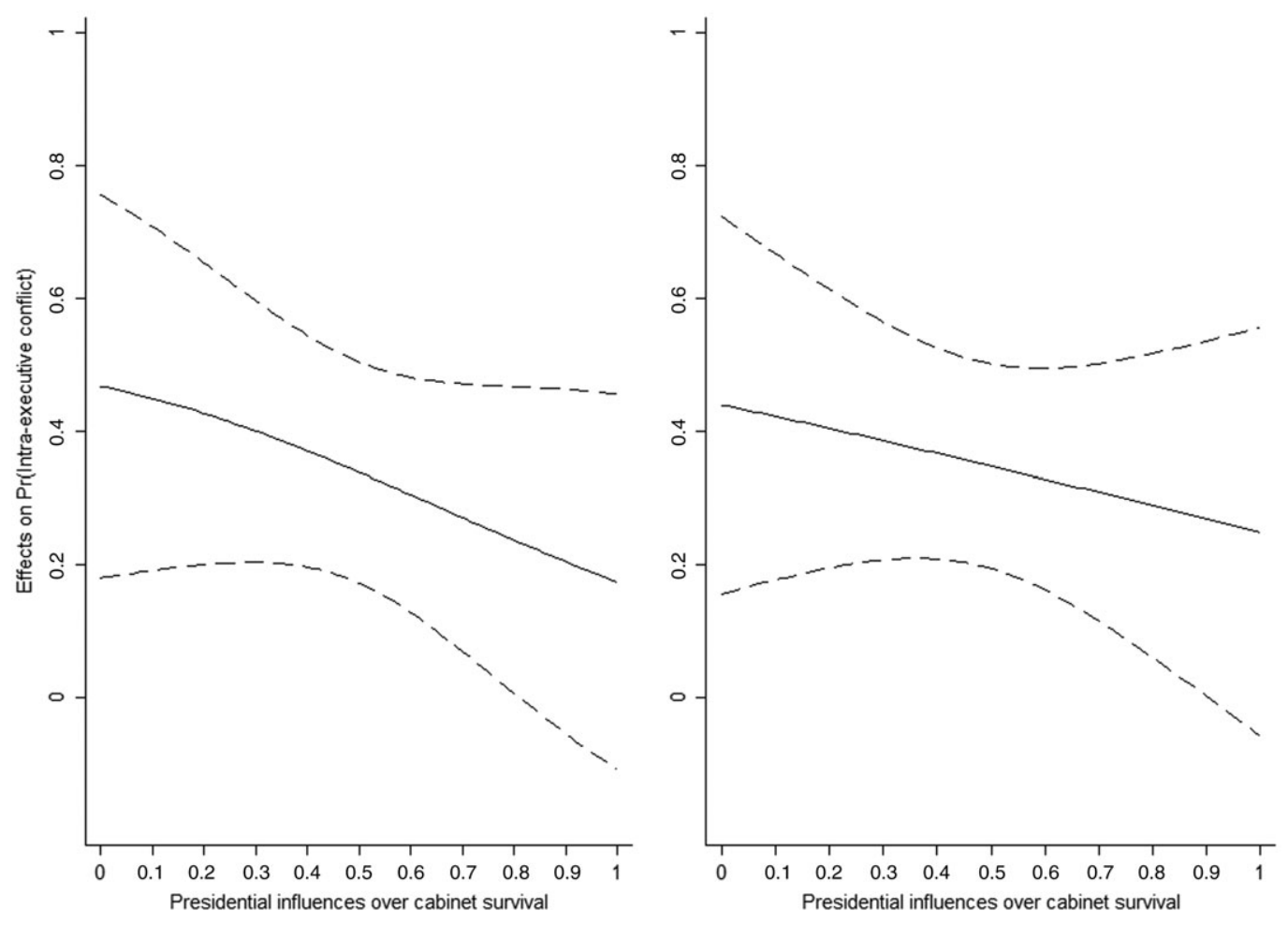

Figure 4. The conditional effects of cohabitation on the predicted probability of intra-executive conflicts. Note: Left panel: no control model, right panel: control model.

other causal condition, LONGDEMO, where $1=$ consolidated democracies and $0=$ otherwise, which is supposed to explain the degree of conflict within the executive branch. Another way to check the robustness is to change the calibration thresholds (Skaaning, 2011; Glaesser and Cooper, 2014). Goplerud and Schleiter (2016) developed a detailed index of assembly dissolution power for all the relevant actors (0-10). For this continuous explanatory factor in the raw data, this paper chose alternative breakpoints, namely, power scores for the president larger than 4 , to separate some cases from others. The final method is to change the frequency thresholds (Skaaning, 2011). In the original analysis, this study used all configurations representing at least one case, but in the robustness analysis, the frequency thresholds are raised to two cases (Appendix F-2).

As shown in Table 2, when considering the conditions of cohabitation and three conditions influencing how the PM controls the executive power, the analysis found that the combination of cohabitation and one of three conditions accounts for intra-executive conflict (COHABIT * [disparl + discab + noconf $] \rightarrow$ CONFLICT). Two types of causal combinations of the four conditions were identified in a large proportion of the complex and intermediate formula. One is COHABIT * disparl ${ }^{\star}$ discab ${ }^{*}$ noconf $\rightarrow$ CONFLICT, while the other is COHABIT * discab * noconf $\rightarrow$ CONFLICT, all showing one of the causal mechanisms as true when different partisan affiliations of presidents and cabinets must coexist with each other [COHABIT] and the president has less influence over cabinet survival [disparl * discab * noconf + discab * noconf], it is more likely for the PM not to cooperate but to scramble for control of the executive branch of government with the president [CONFLICT].

The same procedure was used to obtain the formula for the [0] configurations:csQCA provides us with two causal paths to the [0] outcome. One is cohabit ${ }^{*}[$ DISPARL + noconf ... ] $\rightarrow$ conflict, 
Table 2. Prime minister's control of the executive, cohabitation, and intra-executive conflicts: csQCA

\begin{tabular}{|c|c|c|c|}
\hline & \multicolumn{3}{|c|}{ Resolving Contradictory Configurations } \\
\hline & $50 \%$ threshold & $60 \%$ threshold & $\begin{array}{l}\text { Ratios of configuration to } \\
\text { non-configuration percentages }\end{array}$ \\
\hline \multirow[t]{4}{*}{ Original } & $\mathrm{C}[1]: \mathrm{COHABIT}^{*}$ discab $^{*}$ noconf & $\mathrm{C}[1]: \mathrm{COHABIT}{ }^{*}$ disparl * discab * noconf & $\mathrm{C}[1]:$ COHABIT * discab * noconf \\
\hline & $\mathrm{P}[1]: \mathrm{COHABIT}^{*}$ discab * noconf & $\mathrm{P}[1]: \mathrm{COHABIT}{ }^{*}$ disparl * noconf & $\mathrm{P}[1]: \mathrm{COHABIT}^{*}$ discab * noconf \\
\hline & $\begin{array}{l}\text { C[0]: cohabit * noconf }+ \text { COHABIT * DISPARL * } \\
\text { DISCAB + disparl * discab * NOCONF }\end{array}$ & $\begin{array}{l}\text { C[0]: cohabit * noconf }+ \text { COHABIT * DISPARL * } \\
\text { DISCAB + DISPARL* noconf }+ \text { disparl * discab * } \\
\text { NOCONF }\end{array}$ & $\begin{array}{l}\text { C[0]: COHABIT * DISPARL * DISCAB + disparl * } \\
\text { discab * NOCONF + cohabit * DISPARL * } \\
\text { discab * noconf }\end{array}$ \\
\hline & $P[0]:$ cohabit + DISCAB + NOCONF & $P[0]:$ cohabit + DISPARL + NOCONF & $\begin{array}{l}\text { P[0]: NOCONF + COHABIT * DISCAB + cohabit * } \\
\text { DISPARL * discab }\end{array}$ \\
\hline \multirow[t]{6}{*}{$\begin{array}{l}\text { Addition of condition: } \\
\quad \text { LONGDEMO }\end{array}$} & $\begin{array}{l}\text { C[1]: COHABIT * disparl * discab * noconf * } \\
\text { longdemo + COHABIT * DISPARL * discab * } \\
\text { noconf * LONGDEMO }\end{array}$ & $\begin{array}{l}\mathrm{C}[1]: \text { COHABIT * disparl }{ }^{\star} \text { discab * noconf * } \\
\quad \text { longdemo }\end{array}$ & $\begin{array}{l}\mathrm{C}[1]: \mathrm{COHABIT} * \text { disparl * discab * noconf * } \\
\text { longdemo }\end{array}$ \\
\hline & $\begin{array}{l}\text { I[1]: COHABIT * disparl * discab * noconf * } \\
\text { longdemo + COHABIT * DISPARL * discab * } \\
\text { LONGDEMO }\end{array}$ & $\begin{array}{l}\text { I[1]: COHABIT * disparl * discab * noconf * } \\
\text { longdemo }\end{array}$ & $\begin{array}{l}\text { I[1]: COHABIT * disparl * discab * noconf * } \\
\text { longdemo }\end{array}$ \\
\hline & $\begin{array}{l}\mathrm{P}[1]: \text { COHABIT * longdemo }+ \text { COHABIT * DISPARL } \\
{ }^{\text {discab }}\end{array}$ & $\mathrm{P}[1]: \mathrm{COHABIT}$ * longdemo & $\mathrm{P}[1]: \mathrm{COHABIT}$ * longdemo \\
\hline & $\begin{array}{l}\text { C[0]: disparl * discab * LONGDEMO + cohabit * } \\
\text { DISPARL* noconf * } \\
\text { LONDGDEMO + COHABIT * DISPARL * DISCAB * } \\
\text { LONGDEMO+ cohabit * disparl * noconf * } \\
\text { longdemo }\end{array}$ & $\begin{array}{l}\text { C[0]: DISPARL * noconf * LONGDEMO + disparl * } \\
\text { discab * LONGDEMO + COHABIT * } \\
\text { DISPARL * DISCAB * LONGDEMO + cohabit * } \\
\text { disparl * noconf * longdemo }\end{array}$ & $\begin{array}{l}\text { C[0]: COHABIT * DISPARL * DISCAB * } \\
\text { LONGDEMO + cohabit * disparl * noconf * } \\
\text { LONDEMO + disparl * discab * } \\
\text { NOCONF * LONGDEMO }\end{array}$ \\
\hline & $\begin{array}{l}\text { I[0]: disparl * discab * LONGDEMO + cohabit * } \\
\text { DISPARL * noconf + COHABIT * DISPARL * } \\
\text { DISCAB + cohabit * noconf * longdemo }+ \\
\text { cohabit * disparl * longdemo }\end{array}$ & $\begin{array}{l}\text { I[0]: DISPARL * noconf }+ \text { disparl * discab * } \\
\text { LONGDEMO + COHABIT * DISPARL * DISCAB + co- } \\
\text { habit * noconf * longdemo + cohabit * disparl } \\
\text { * longdemo }\end{array}$ & $\begin{array}{l}\text { I[0]: COHABIT * DISPARL * DISCAB + cohabit * } \\
\text { disparl * noconf * LONDEMO + disparl * } \\
\text { discab * NOCONF }\end{array}$ \\
\hline & $\mathrm{P}[0]$ : cohabit+ DISCAB+ disparl*LONGDEMO & $\mathrm{P}[0]:$ cohabit + LONGDEMO & $\begin{array}{l}\text { P[0]: NOCONF + COHABIT * DISCAB + cohabit * } \\
\text { discab * LONFDEMO }\end{array}$ \\
\hline
\end{tabular}


Resolving Contradictory Configurations

\begin{tabular}{|c|c|c|c|}
\hline & \\
\hline & $50 \%$ threshold & $60 \%$ threshold & $\begin{array}{l}\text { Ratios of configuration to } \\
\text { non-configuration percentages }\end{array}$ \\
\hline \multirow{4}{*}{$\begin{array}{l}\text { Change the Calibration } \\
\text { Thresholds: DISPARL }\end{array}$} & $\mathrm{C}[1]: \mathrm{COHABIT}{ }^{*}$ disparl * discab * noconf & $\mathrm{C}[1]: \mathrm{COHABIT}{ }^{*}$ disparl ${ }^{*}$ discab * noconf & $C[1]:$ COHABIT * discab * noconf \\
\hline & $\mathrm{P}[1]: \mathrm{COHABIT}{ }^{*}$ disparl & $\mathrm{P}[1]: \mathrm{COHABIT}^{*}$ disparl & $\mathrm{P}[1]: \mathrm{COHABIT}{ }^{*}$ discab * noconf \\
\hline & $\begin{array}{l}\text { C[0]: cohabit * noconf }+ \text { COHABIT * DISPARL + } \\
\text { DISPARL * discab }\end{array}$ & $\begin{array}{l}\text { C[0]: cohabit * noconf }+ \text { COHABIT * DISPARL }+ \\
\quad \text { DISPARL * discab }\end{array}$ & $\begin{array}{l}\text { C[0]: DISPARL * discab * } \\
\text { NOCONF + COHABIT * DISPARL * DISCAB }+ \\
\text { cohabit * DISPARL * noconf } \\
\text { C[0]: DISPARL * DISCAB * } \\
\text { noconf + COHABIT * DISPARL * DISCAB + cohabit } \\
{ }^{*} \text { DISPARL * discab }\end{array}$ \\
\hline & $\mathrm{P}[0]:$ cohabit + DISPARL & $\mathrm{P}[0]$ : cohabit + DISPARL & $\begin{array}{l}\text { P[0]: NOCONF + cohabit * } \\
\text { DISPARL + COHABIT * DISCAB } \\
\text { P[0]: NOCONF + cohabit * } \\
\text { DISPARL + DISPARL * DISCAB }\end{array}$ \\
\hline \multirow{4}{*}{$\begin{array}{l}\text { Change the Frequency } \\
\text { Thresholds: Two } \\
\text { Cases }\end{array}$} & C[1]: COHABIT * discab * noconf & $\mathrm{C}[1]: \mathrm{COHABIT}$ * disparl * discab * noconf & $C[1]:$ COHABIT * discab * noconf \\
\hline & $\mathrm{P}[1]: \mathrm{COHABIT}$ * discab * noconf & $\mathrm{P}[1]:$ COHABIT * disparl * noconf & $\mathrm{P}[1]:$ COHABIT * discab * noconf \\
\hline & $\begin{array}{l}\text { C[0]: cohabit * noconf }+ \text { DISPARL * DISCAB * } \\
\text { noconf }+ \text { disparl * discab * NOCONF }\end{array}$ & $\begin{array}{l}\text { C[0]: cohabit * noconf }+ \text { DISPARL* noconf }+ \text { dis- } \\
\text { parl * discab * NOCONF }\end{array}$ & $\begin{array}{l}\text { C[0]: COHABIT * DISPARL * DISCAB + disparl * } \\
\text { discab * NOCONF + cohabit * DISPARL * } \\
\text { discab * noconf }\end{array}$ \\
\hline & $\mathrm{P}[0]$ : cohabit + DISCAB + NOCONF & $\mathrm{P}[0]$ : cohabit + DISCAB + NOCONF & $\begin{array}{l}\text { P[0]: NOCONF + COHABIT * DISCAB + cohabit * } \\
\text { DISPARL * discab }\end{array}$ \\
\hline
\end{tabular}

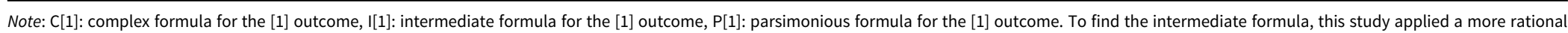

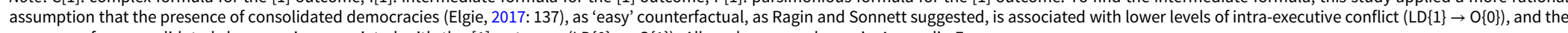
presence of unconsolidated democracies associated with the $[1]$ outcome $(\operatorname{LD}\{0\} \rightarrow O\{1\})$. All analyses are shown in Appendix $F$. 
illustrating that no matter the extent to which a president poses a threat to the survival of government [DISPARL + noconf...] , in the case of non-cohabitation [cohabit], intra-executive competition is rare [conflict]. The other is COHABIT ${ }^{*}$ DISPARL ${ }^{\star}$ DISCAB $\rightarrow$ conflict. It is read as follows: 'During the period of cohabitation [COHABIT] in all semi-presidential democracies where presidential influence on cabinet termination is higher [DISPARL ${ }^{\star}$ DISCAB], relations between the president and the PM are peaceful [conflict].' When some logical remainders are included to obtain the parsimonious formula, a large proportion of causal combinations of the four conditions is cohabit + DISPARL + DISCAB + NOCONF $\rightarrow$ conflict. This confirms our theoretical expectations: intra-executive confrontations decrease when the president and the cabinet share an ideological orientation or the president has greater room to manoeuvre when determining cabinet survival. Compared to the path COHABIT ${ }^{\star}$ [disparl + discab + noconf] covering the observed [1] outcome cases, we found that this type of path was not associated with the [0] outcome.

\section{Discussion}

This article answers why intra-executive conflict varies across semi-presidential democracies. Some scholars conclude that intra-executive competition tends to be higher when the president holds less power to dismiss the cabinet (Protsyk, 2005a; Protsyk, 2006; Sedelius and Mashtaler, 2013), while Elgie (2017) confirms the positive effects of presidential power on the likelihood of intra-executive conflict. This study's findings, however, show that presidential influence over cabinet survival is a significant predictor of intra-executive conflict. Further, research confirms that cohabitation is more prone to intra-executive conflict (Protsyk, 2005a; Protsyk, 2006; Sedelius and Mashtaler, 2013), which is conditioned on a broad scope of presidential constitutional power (Elgie, 2017). The study further shows that the effects of cohabitation on the chances of an intra-executive conflict depend on the president's ability to threaten cabinet survival. Finally, the study integrates the above factors to construct an index of prime ministerial autonomy, confirming that its relationship with the probability of intra-executive conflict is represented by an inverted U-shaped curve. This argument is not entirely new, as existing research shows an inverse relationship between the strength of presidential powers to dismiss and the level of intra-executive conflict and conditional effects of cohabitation on intra-executive relationships. This study contributes to this relationship, considering the interplay of constitutional and non-constitutional factors, with focus on the president's ability to threaten a cabinet's survival. Table 3 summarises the comparisons between previous findings and present results.

The only incentive to motivate a president to enter into conflict in this model is cohabitation. It would certainly add value if the paper would have engaged in other motivational mechanisms, for example by looking more closely into cases where cohabitation is not the main cause of conflict. Based on the results of the regression model, two motivational factors - the president with experience as a party leader and age of democracy - had significant effects on the likelihood of conflict (Appendix E). The study removed the cohabitation condition from the model and replaced it with the two other motivational factors for causal explanation. However, this account offers a far less precise explanation of intra-executive conflict than the cohabitation condition, leaving more cases under-explained (Appendix F-3). In addition, it accounts for only a few deviant cases when included as the other causal condition in conjunction with the cohabitation condition (Appendix F4). Despite cohabitation proving to be a significant institutional factor predicting intra-executive conflict, future research should consider individual-level determinants of presidents' motivations to open war against premiers.

This study confirmed that the relationship between prime ministerial autonomy and intraexecutive conflict is represented by an inverted U-shaped curve. A fundamental point merits further discussion. The findings are somewhat skewed by two exceptional cases of president- 
Table 3. The comparisons between previous findings and present results

\begin{tabular}{|c|c|c|c|c|}
\hline & Protsyk (2006) & Sedelius and Mashtaler (2013) & Elgie (2017) & Present Results \\
\hline $\begin{array}{l}\text { Number of Semi-presidential } \\
\text { Regimes }\end{array}$ & 8 & 8 & 14 & 17 \\
\hline Period & 1991-2002 & $1991-2011$ & 1995-2015 & $1990-2015$ \\
\hline Number of cabinets & 67 & 76 & 139 & 187 \\
\hline Methods & Descriptive statistics & Descriptive statistics & $\begin{array}{l}\text { Quantitative, csQCA, case } \\
\text { studies }\end{array}$ & Quantitative, csQCA \\
\hline Findings & COHABIT + discab $\rightarrow$ CONFLICT & COHABIT + discab $\rightarrow$ CONFLICT & $\begin{array}{l}\text { COHABIT * PRESPOWER } \rightarrow \\
\quad \text { CONFLICT }\end{array}$ & $\begin{array}{l}\text { 1. COHABIT * presinflu- } \\
\text { ence } \\
\rightarrow \text { CONFLICT } \\
\text { 2. Prime ministerial } \\
\text { autonomy } R \text { conflict = } \\
\text { an inverted } U \text { curve }\end{array}$ \\
\hline $\begin{array}{l}\text { Speak to this study's } \\
\text { findings }\end{array}$ & $\begin{array}{l}\text { On the left side of the curve: intra- } \\
\text { executive confrontations decrease } \\
\text { when the president has greater room } \\
\text { to manoeuvre when determining cabi- } \\
\text { net survival }\end{array}$ & $\begin{array}{l}\text { On the left side of the curve: intra- } \\
\text { executive confrontations decrease } \\
\text { when the president has greater room } \\
\text { to manoeuvre when determining cabi- } \\
\text { net survival }\end{array}$ & $\begin{array}{l}\text { The effects of cohabitation on the } \\
\text { chances of an intra-executive } \\
\text { conflict depend on presidential } \\
\text { constitutional power }\end{array}$ & - \\
\hline $\begin{array}{l}\text { This study's findings contrib- } \\
\text { ute to existing research }\end{array}$ & $\begin{array}{l}\text { 1. The interplay of constitutional and } \\
\text { non-constitutional factors } \\
\text { 2. A nuanced measure of the president's } \\
\text { ability to threaten cabinet survival }\end{array}$ & $\begin{array}{l}\text { 1. The interplay of constitutional and } \\
\text { non-constitutional factors } \\
\text { 2. A nuanced measure of the president's } \\
\text { ability to threaten cabinet survival }\end{array}$ & $\begin{array}{l}\text { A focus on the president's ability } \\
\text { to threaten cabinet survival in- } \\
\text { stead of a broad scope of presi- } \\
\text { dential constitutional power }\end{array}$ & - \\
\hline
\end{tabular}

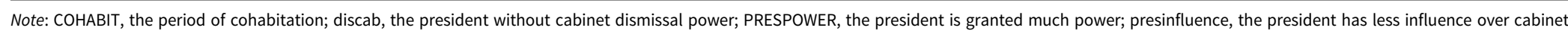

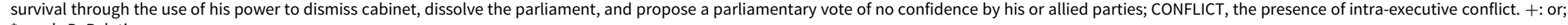
*: and; $R$, Relation. 
parliamentarism: Austria and Iceland, where presidents perceive their roles as political arbiters and only to act as political leaders when the prevailing political system does not work. Further, one case where the president has unilateral cabinet dismissal powers in this dataset is Russia, which has questionable levels of democracy. Our theoretical expectations were still confirmed excluding the three cases mentioned above, while doing so it does leave the lower left end of the inverted U-curve covered by empirical data on the Ukraine's cabinets (1996-2006). Future research should include more cases of president-parliamentary democracies outside Europe to test the proposition: for example, Taiwan is a case where strong presidents always handpick premiers, thus mitigating intra-executive competition (Wu and Tsai, 2011).

Our results imply that a higher or lower extent of prime ministerial autonomy tends to reduce the likelihood of intra-executive conflict. At least two policy implications may follow. First, scholars of semi-presidentialism may pay close attention to institutional design as the president's power to terminate the cabinet can ensure the PM's compliance, and, accordingly, ease the conflict. However, semi-presidential regimes, where a powerful president can unilaterally dismiss the cabinet, generally have a worse democratic performance (Elgie, 2011b; Kim, 2015; Sedelius and Linde, 2018). In the bigger scheme of things, intra-executive conflict may be preferable to presidential overreach. Second, efforts to shape peaceful intra-executive relations by reducing presidential influence over cabinet survival might be more effective if the use of such a strategy is conditional on the electoral system facilitating the coexistence of president and PM of the same political orientation. Although previous studies have questioned whether cohabitation poses any serious threat to democracy (Kirschke, 2007; Elgie, 2010; Kim, 2015), there is no evidence that the period of united executive is more susceptible to democratic failure. In sum, an effective institutional design to lower the extent of intra-executive confrontation should favour greater prime ministerial autonomy.

Acknowledgements. A previous version of this paper was presented at the 2018 General Conference of the European Consortium for Political Research. For their comments and suggestions on earlier drafts of this paper, I would like to thank Sébastien Lazardeux, Thomas Sedelius, and Tapio Raunio. All remaining errors remain mine.

Supplementary material. To view supplementary material for this article, please visit https://doi.org/10.1017/ S1755773921000072.

\section{References}

Baylis, T.A. (1996), 'Presidents versus prime ministers: shaping executive authority in Eastern Europe', World Politics 48(3): 297-323.

Bjørnskov, C. and M. Rode (2020), 'Regime types and regime change: a new dataset on democracy, coups, and political institutions', Review of International Organizations 15(2):531-551.

Cienski, J. (2010), Polish President, Prime Minister at Loggerheads, The World. Retrieved from https://www.pri.org/stories/ 2009-01-28/polish-president-prime-minister-loggerheads.

Crowther, W. and Y. Josanu (2004), 'Moldova', in S. Berglund, J. Ekman and F.H. Aarebrot (eds.), The Handbook of Political Change in Eastern Europe, Cheltenham: Edward Elgar, pp. 549-593.

Elgie, R. (1999), 'The politics of semi-presidentialism', in R. Elgie (ed.), Semi-presidentialism in Europe, Oxford: Oxford University Press, pp. 1-21.

Elgie, R. (2010), 'Semi-presidentialism, cohabitation and the collapse of electoral democracies, 1990-2008', Government and Opposition 45(1): 29-49.

Elgie, R. (2011a), 'Semi-presidentialism in Western Europe', in R. Elgie, S. Moestrup and Y.S. Wu (eds.), Semi-Presidentialism and Democracy, New York: Palgrave Macmillan, pp. 81-97.

Elgie, R. (2011b), Semi-presidentialism: Sub-types and Democratic Performance, New York: Oxford University Press.

Elgie, R. (2017), 'Presidential power and president cabinet conflict', in R. Elgie (ed.), Political Leadership: A Pragmatic Institutionalist Approach, New York: Palgrave Macmillan, pp. 127-149.

Fernandes, J.M. and P.C. Magalhães (2016), 'Government survival in semi-presidential regimes', European Journal of Political Research 55(1): 61-80.

Frye, T. (1997), 'A politics of institutional choice: post-communist presidencies', Comparative Political Studies 30(5): 523-552. 
Gallagher, T. and V. Andrievici (2008), 'Romania: political irresponsibility without constitutional safeguards', in R. Elgie and S. Moestrup (eds.), Semi-Presidentialism and Democratization in Central and Eastern Europe, Manchester: Manchester University Press, pp. 138-158.

Geddes, B., J. Wright and E. Frantz (2014), 'Autocratic breakdown and regime transitions: a new dataset', Perspectives on Politics 12(2): 313-331.

Gherghina, S. and M. Hein (2016), 'Romania', in A. Fruhstorfer and M. Hein (eds.), Constitutional Politics in Central and Eastern Europe: From Post-Socialist Transition to the Reform of Political Systems, Wiesbaden: Springer VS, pp. 173-198.

Glaesser, J. and B. Cooper (2014), 'Exploring the consequences of a recalibration of causal conditions when assessing sufficiency with fuzzy set QCA', International Journal of Social Research Methodology 17(4): 387-401.

Goplerud, M. and P. Schleiter (2016), 'An index of assembly dissolution powers', Comparative Political Studies 49(4): 427-456.

Hellman, J. (1996), 'Constitutions and economic reform in the postcommunist transitions', East European Constitutional Review 5:46-53.

Jalali, C. (2011), 'The president is not a passenger: Portugal's evolving semi-presidentialism', in R. Elgie, S. Moestrup and Y.S. Wu (eds.), Semi-Presidentialism and Democracy, New York: Palgrave Macmillan, pp. 156-173.

Kim, Y.H. (2015), 'A troubled marriage? Divided minority government, cohabitation, presidential powers, presidentparliamentarism and semi-presidentialism', Government and Opposition 50(4): 652-681.

Kirschke, L. (2007), 'Semi-presidentialism and the perils of power-sharing in neopatrimonial states', Comparative Political Studies 40(11): 1372-1394.

Köker, P. (2017), Presidential Activism and Veto Power in Central and Eastern Europe, New York: Palgrave Macmillan.

Krushelnycky, A. (2001), Ukraine: Yushchenko Fails Confidence Vote, Radio Free Europe/Radio Liberty. Retrieved from https://www.rferl.org/a/1096303.html.

Laver, M. and K. Shepsle (1996), Making and Breaking Governments: Cabinets and Legislatures in Parliamentary Democracies, New York: Cambridge University Press.

Lazardeux, S.G. (2015), Cohabitation and Conflicting Politics in French Policymaking, New York: Palgrave Macmillan.

Martin, L.W. (2004), 'The government agenda in parliamentary democracies', American Journal of Political Science 48(3): 445-461.

Martin, L.W. and G. Vanberg (2014), 'Parties and policymaking in multiparty governments: the legislative median, ministerial autonomy, and the coalition compromise', American Journal of Political Science 58(4): 979-996.

McGregor, J. (1994), 'The presidency in East Central Europe', RFE/RL Research Report 3(2): 23-31.

Metcalf, L.K. (2000), 'Measuring presidential power', Comparative Political Studies 33(5): 660-685.

Müller, W.C. and K. Strøm (2000), 'Coalition governance in Western Europe: an introduction', in W.C. Müller and K. Strøm (eds.), Coalition Governments in Western Europe, Oxford: Oxford University Press, pp. 1-31.

Neto, O.A. and K. Strøm (2006), 'Breaking the parliamentary chain of delegation: presidents and non-partisan cabinet members in European democracies', British Journal of Political Science 36(4): 619-643.

Neto, O.A. and M.C. Lobo (2009), 'Portugal's semi-presidentialism (re)considered: an assessment of the president's role in the policy process, 1976-2006', European Journal of Political Research 48(2): 234-255.

Polskie Radio (2010), Civic Platform Overhauling the Constitution, Polskie Radio. Retrieved from http://www2.polskieradio. $\mathrm{pl} / \mathrm{eo} /$ dokument.aspx?iid=125258.

Protsyk, O. (2005a), 'Politics of intra-executive conflict in semipresidential regimes in Eastern Europe', East European Politics and Society 19(2): 135-160.

Protsyk, O. (2005b), 'Prime ministers' identity in semi-presidential regimes: constitutional norms and cabinet formation outcomes', European Journal of Political Research 44(5): 721-748.

Protsyk, O. (2006), 'Intra-executive competition between president and prime minister: patterns of institutional conflict and cooperation under semi-presidentialism', Political Studies 54(2): 219-244.

Ragin, C.C. (2008), Redesigning Social Inquiry: Set Relations in Social Research, Chicago: University of Chicago Press.

Ragin, C.C. and J. Sonnett (2004), 'Between complexity and parsimony: limited diversity, counterfactual cases, and comparative analysis', in S. Kropp and M. Minkenberg (eds.), Vergleichen in der Politikwissenschaft, Wiesbaden: VS Verlag fur Sozialwissenschaften, pp. 180-197.

Raunio, T. and T. Sedelius (2019), 'Shifting power-centres of semi-presidentialism: exploring executive coordination in Lithuania', Government and Opposition 54(4): 637-660.

Roscigno, V.J. and R. Hodson (2004), 'The organizational and social foundations of worker resistance', American Sociological Review 69(1): 14-39.

Rihoux, B. and G. De Meur (2009), 'Crisp-set qualitative comparative analysis (csQCA)', in B. Rihoux and C.C. Ragin (eds.), Configurational Comparative Methods: Qualitative Comparative Analysis (QCA) and Related Techniques, Thousand Oaks: SAGE, pp. 33-68.

Schleiter, P. and E. Morgan-Jones (2009a), 'Constitutional power and competing risks: monarchs, presidents, prime ministers, and the termination of East and West European cabinets', American Political Science Review 103(3): 496-512. 
Schleiter, P. and E. Morgan-Jones (2009b), 'Party government in Europe? Parliamentary and semi-presidential democracies compared', European Journal of Political Research 48(5): 665-693.

Schleiter, P. and E. Morgan-Jones (2010), 'Who's in charge? Presidents, assemblies, and the political control of semipresidential cabinets', Comparative Political Studies 43(11): 1415-1441.

Schneider, C.Q. and C. Wagemann (2010), 'Standards of good practice in qualitative comparative analysis (QCA) and fuzzysets', Comparative Sociology 9(3): 397-418.

Sedelius, T. and J. Ekman (2010), 'Intra-executive conflict and cabinet instability: effects of semi-presidentialism in Central and Eastern Europe', Government and Opposition 45(4): 505-530.

Sedelius, T. and J. Linde (2018), 'Unravelling semi-presidentialism: democracy and government performance in four distinct regime types', Democratization 25(1): 136-157.

Sedelius, T. and O. Mashtaler (2013), 'Two decades of semi-presidentialism: issues of intra-executive conflict in Central and Eastern Europe 1991-2011', East European Politics 29(2): 109-134.

Shevtsova, L.F. and M.H. Eckert (2000), 'The problem of executive power in Russia', Journal of Democracy 11(1): 32-39.

Shugart, M.S. and J.M. Carey (1992), Presidents and Assemblies: Constitutional Design and Electoral Dynamics, Cambridge: Cambridge University Press.

Siaroff, A. (2003), 'Comparative presidencies: the inadequacy of the presidential, semi-presidential and parliamentary distinction', European Journal of Political Research 42(3): 287-312.

Skaaning, S.E. (2011), 'Assessing the robustness of crisp-set and fuzzy-set QCA results', Sociological Methods \& Research 40(2): 391-408.

Tavits, M. (2008), Presidents with Prime Ministers: Do Direct Elections Matter?, Oxford: Oxford University Press.

Thiem, A. (2014), 'Navigating the complexities of qualitative comparative analysis: case numbers, necessity relations and model ambiguities', Evaluation Review 38(6): 487-513.

Warwick, P.V. (1999), 'Ministerial autonomy or ministerial accommodation? Contested bases of government survival in parliamentary democracies', British Journal of Political Science 29(2): 369-394.

White, S. (1999), 'Russia', in R. Elgie (ed.), Semi-presidentialism in Europe. Oxford: Oxford University Press, pp. $216-231$.

Wu, Y.S. and J.H. Tsai (2011), 'Taiwan: democratic consolidation under president-parliamentarism', in R. Elgie, S. Moestrup and Y.S. Wu (eds.), Semi-Presidentialism and Democracy. New York: Palgrave Macmillan, pp. 174-191.

Yan, H.T. (2018), 'The survival of minority government under semi-presidentialism: a perilous combination of powerful president and parliament', Paper Presented at $46^{\text {th }}$ ECPR Joint Sessions of Workshops, Nicosia, Cyprus, 10-14 April.

Cite this article: Yan H-T (2021). Prime ministerial autonomy and intra-executive conflict under semi-presidentialism. European Political Science Review 13, 285-306. https://doi.org/10.1017/S1755773921000072 